\title{
Peningkatan Prestasi Belajar IPS Melalui Metode Permainan Pasang Pohon Berbuah
}

\author{
Endang Susilowati \\ SMP Negeri 2 Menganti Gresik \\ Email : esusilowati40@yahoo.com
}

\begin{abstract}
Abstrak
Penelitian ini bertujuan untuk mengetahui peningkatan prestasi belajar siswa dalam pembelajaran IPS melalui metode Permainan Pasang Pohon Berbuah. Penelitian ini merupakan penelitian tindakan kelas di kelas VII A SMPN 2 Menganti Gresik yang dilakukan dalam 3 siklus. Siklus1, 2 , dan 3 masing-masing terdiri dari 2 pertemuan. Setiap siklus meliputi tahapan planning (rencana), action (tindakan), observation (pengamatan), dan reflection (refleksi). Teknik pengumpulan data dilakukan dengan metode observasi dan dokumentasi. Instrumen pengumpul data yang digunakan berupa : 1) soal tes formatif ; 2) lembar observasi siswa. Hasil penelitian menunjukkan bahwa penerapan metode Permainan Pasang Pohon Berbuah terbukti dapat meningkatkan prestasi belajar siswa pada mata pelajaran IPS pada bab" Kerajaan Islam di Indonesia".
\end{abstract}

Kata Kunci : Prestasi belajar, Metode Permainan Pasang Pohon Berbuah

\section{PENDAHULUAN}

Di dalam kurikulum KTSP kelas VII bidang studi IPS terdapat bab yang mempelajari tentang Kerajaan Islam di Indonesia. Materi yang dibahas dalam bab tersebut mulai awal proses masuknya Islam di Indonesia sampai dengan perkembangan kerajaan-kerajaan Islam di Indonesia yang jumlahnya sangat banyak. Banyak siswa yang merasa kesulitan dan merasa bosan mempelajari materi tersebut karena begitu banyak nama kerajaan, nama-nama raja, peristiwa yang menyangkut kerajaan, dan penyebab runtuhnya kerajaan-kerajaan Islam serta peninggalann masing-masing kerajaan Islam.

Prestasi belajar siswa kelas VII di SMPN 2 Menganti tahun 2016-2017 dalam bidang studi IPS pada bab : "Kerajaan Islam di Indonesia", tidak begitu 
menggembirakan, dalam arti banyak siswa yang kurang antusias terlihat dari sikap siswa yang pasif dalam proses pembelajaran, kurang semangat terlihat dari enggannya siswa bertanya atau menjawab pertanyaan dari guru, terkesan agak malas beraktivitas terlihat dari banyak siswa yang mengantuk dan tidak ada respon terhadap pelajaran. Pada akhir pembelajaran guru telah mengadakan tes formatif di kelas VIIA namun hasilnya hanya 12 siswa yang mencapai KKM atau hanya 37,5,5\% siswa yang mencapai nilai KKM yang telah disepakati yaitu 75. Sedangkan 20 siswa mendapat nilai di bawah KKM atau 67,5\% siswa mendapat nilai di bawah KKM. Sedangkan di kelas VII lainnya kurang lebih juga hampir sama. Kondisi tersebut sangat memprihatinkan mengingat pelajaran IPS pada topik tersebut tidak terlalu sulit namun ternyata hasil belajar siswa tidak menggembirakan.

Peneliti mencoba mengidentifikasi masalah yang terjadi di kelas VIIyaitu: (1). Banyak siswa yang kurang antusias terhadap pelajaran IPS khususnya pada bab"Kerajaan Islam di Indonesia”.(2).Banyak siswa yang kurang semangat mengikuti proses pembelajaran. (3).Banyak siswa merasa bosan mempelajari nama-nama kerajaan, nama-nama raja, tahun, perkembangan kerajaan, penyebab keruntuhan kerajaan, dan peninggalannya. (3). Prestasi belajar siswa rendah. (4). Metode yang diapakai peneliti pada waktu itu adalah tanya jawab secara klasikal ternyata kurang berhasil dalam membantu siswa mencapai kompetensi yang diharapkan.

Peneliti selaku guru IPS berusaha mengadakan introspeksi dan diskusi dengan teman-teman sesama guru IPS yang tergabung dalam tim MGMPS IPS SMPN 2 Mengantitentang apa sebabnya siswa kurang aktif, kurang semangat dan hasil belajar siswa kelas VII kurang bagus. Kemudian kami berkesimpulan bahwa kami perlu mencoba memperbaiki agar cara pengajaran kami sesuai dengan Peraturan Pemerintah No. 19 tahun 2005, Pasal 19 Ayat 1 Peraturan Pemerintah Nomer 19 Tahun 2005, Pasal 19, ayat 1 menyatakan bahwa proses pembelajaran pada satuan pendidikan diselenggarakan secara interaktif, inspiratif, menyenangkan, menantang, memotivasi peserta didik untuk berpartisipasi aktif, serta memberikan ruang yang cukup bagi prakarsa, kreativitas, sesuai dengan bakat, minat, dan perkembangan fisik serta psikologis peserta didik. Dalam Undang-undang Guru dan Dosen disebutkan bahwa seorang guru harus memiliki kompetensi pedagogik, kompetensi profesional, kompetensi kepribadian dan kompetensi sosial. Dalam kompetensi pedagogik dan 
profesional maka guru diharapkan mampu mengkaji di setiap pembelajarannya agar pembelajaran yang dilakukan lebih bermakna.

Kemudian peneliti membuat perencanaan pembelajaran dengan mencoba menciptakan sendiri metode yang penulis beri nama "Metode Permainan Pasang Pohon Berbuah" . Dengan penggunaan metode tersebut diharapkan siswa dapat lebih semangat belajar, lebih antusias dalam aktivitas belajar sehingga hasil belajar siswa akan lebih meningkat.

Metode Permainan Pasang Pohon Berbuah dipilih oleh peneliti karena di dalam langkah-langkah pelaksanaan metode tersebut siswa mau tidak mau akan bekerjasama dalam kelompok, akan aktif menjawab pertanyaan, dan akan lebih semangat untuk menjadi tim pemenang permainan tersebut. Metode Permainan Pasang Pohon Berbuah berupa permainan antar kelompok dimana kelompok saling beradu dalam menjawab pertanyaan dengan benar agar dapat memasang buah pada pohonnya dan untuk mendapatkan nilai yang tinggi.

Rumusan masalah dalam penelitian tindakan ini yaitu : (1). Bagaimana cara melaksanakan Metode Permainan Pasang Pohon Berbuah dalam mengajarkan materi "Kerajaan Islam di Indonesia"?(2). Apakah penggunaan metode Permainan Pasang Pohon Berbuah dapat meningkatkan prestasi belajar IPS siswa kelas VIIA SMP Negeri 2 Menganti pada materi“Kerajaan Islam di Indonesia?”

Tujuan penelitian ini adalah : (1)Untuk mengetahui bagaimana cara melaksanakan metode Permainan Pasang Pohon Berbuah dalam mengajarkan materi Perkembangan Islam di Indonesia. (2)Untuk mengetahui apakah penggunaan metode Permainan Pasang Pohon Berbuahdapat meningkatkan prestasi belajar IPS siswa kelas VII SMP Negeri 2 Menganti pada materi : "Kerajaan Islam di Indonesia ".

Manfaat penelitian ini adalah (1). Bagi guru, hasil dan temuan penelitian ini dapat memberikan informasi tentang bagaimana cara melaksanakan pembelajaran IPS menggunakan metode permainan pasang pohon berbuah pada materi“Perkembangan kerajaan Islam di indonesia”.. (2). Bagi sekolah, sekolah dapat membuat kebijakan yang tepat dalam upaya meningkatkan prestasi belajar siswa khususnya pada mata pelajaran IPS. (3). Bagi siswa, dapat meningkatkan motiviasi belajar dan prestasi belajar dalam mencapai tujuan belajar. (4). Bagi dunia pendidikan, secara umum 
dapat memberikan sumbangan pemikiran bagi guru IPS dalam mengajar dan meningkatkan pemahaman siswa belajar IPS.

Prestasi belajar adalah suatu hasil yang telah dicapai pebelajar dalam kegiatan belajarnya (dari yang telah dilakukan, dikerjakan, dan sebagainya), sebagaimana dijelaskan dalam Kamus Besar Bahasa Indonesia (1995: 787). Dari pengertian ini, maka hasil belajar adalah penguasaanpengetahuan atau keterampilan yang dikembangkan oleh mata pelajaran, lajimnya ditunjukkan dengan nilai tes atau angka nilai yang diberikan oleh guru.

Metode Permainan Pasang Pohon Berbuah berupa permainan antar kelompok dimana kelompok saling beradu dalam menjawab pertanyaan dengan benar agar dapat memasang buah pada pohonnya dan untuk mendapatkan nilai yang tinggi. Nilai tiap kelompok dapat dilihat dari berapa jumlah buah yang terpasang pada pohon milik mkelompok masing-masing.

Alat-alat yang diperlukan dalam melaksanakan pembelajaran menggunakan metode Permainan Pasang Pohon Berbuah ini adalah :

1. Kertas gambar sebanyak 8 lembar karena siswa dalam satu kelas dibagi dalam 8 kelompok.

2. Spidol warna untuk menggambar pohon tanpa buah pada kertas gambar.

3. Lem kertas / isolasi untuk menempelkan kertas gambar pada papan tulis.

4. Kertas warna untuk menuliskan jawaban dan selanjutnya dibentuk mirip buah ditempelkan pada kertas gambar jika jawabannya benar.

Cara melaksanakan pembelajaran menggunakan Metode Permainan Pasang Pohon Berbuah adalah sebagai berikut :

1. Kegiatan Pendahuluan

Pada bagian pendahuluan, guru membuka pelajaran dengan salam, kemudian mengecek kondisi kelas, menyampaikan tujuan pembelajaran, menyampaikan metode pembelajaran yang akan dipakai, dan pokok bahasan yang akan dipelajari.

2. Kegiatan Inti

Kegiatan inti diawali dengan kegiatan klasikal selama 10 menit yaitu penjelasan singkat disertai tanya jawab singkat tentang materi Perkembangan Kerajaan Islam di Indonesia. Kemudian guru meminta siswa membentuk kelompok menjadi 8 kelompok dalam satu kelas. Selanjutnya guru membagikan kertas gambar, isolasi, spidol dan 
kertas warna kepada tiap kelompok. Tiap kelompok diminta menggambar pohon tanpa buah dan menempelkannya di papan tulis. Tiap kelompok diminta membaca buku paket pada bab Kerajaan Islam di Indonesia 10 menit.

Guru memulai permainan dengan membacakan soal nomor satu kemudian memberi kesempatan siswa menulis jawaban pada kertas warna selama 3 menit kemudian tiap kelompok diminta menguumpulkan tepat waktu. Langsung guru mengecek jawaban tiap kelompok. Kelompok yang jawabannya benar diminta membentuk kertas warna tadi menjadi bentuk buah dan ditempelkan pada kertas gambar di papan tulis. Sedangkan kelompok yang jawabannya salah, kertas warnanya dikembalikan.

Selanjutnya guru membacakan nomor soal berikutnya dengan cara yang sama. Setelah 10 soal selesai dibacakan maka akan dapat diketahui berapa jumlah buah yang ditempelkan di gambar pohon milik masing masing kelompok. Dan juga dapat diketahui berapa nilai masing-masing kelompok. Jika kelompok tersebut menempelkan 10 buah maka nilainya 100. Jika hanya 9 buah maka nilainya 90 , jika hanya 8 buah maka nilainya 80, jika hanya 7 buah maka nilainya 70, jika hanya 6 buah maka nilainya 60 , jika hanya 5 buah maka nilainya 50, jika hanya 4 buah maka nilainya 40, jika hanya 3 buah maka nilainya 30, jika hanya 2 buah maka nilainya 20, dan jika hanya 1 buah maka nilainya 10, dan jika tidak ada buah yang tertempel berarti nilainya 0 .

\section{Kegiatan Penutup}

Kegiatan penutup diawali dengan upaya guru mendorong siswa agar siswa mampu mebuat kesimpulan atas materi pelajaran yang telah dipelajari. Kemudian guru memberi penguatan atas kesimpulan yang telah di buat siswa.

Untuk memperkuat pemahaman siswa terhadap materi pelajaran maka guru memberi tes tertulis dengan memberi 10 soal pilihan ganda.

Untuk menutup pelajaran, guru bertanya kepada siswa tentang perasaan siswa dalam mempelajari materi Kerajaan Islam di Indonesia menggunakan metode permainan pasang berbuah.

\section{METODE PENELITIAN}


1. Analisis data yang penulis pakai

Untuk mengetahui keefektivan suatu kegiatan pembelajaran perlu diadakan analisis data. Pada penelitian ini menggunakan teknik analisis kualitatif deskriptif dan analisis kuantitatif. Analisis kualitatif deskriptif yang dilakukan disini yaitu suatu metode penelitian yang bersifat menggambarkan kenyataan atau fakta sesuai dengan data yang diperoleh dengan tujuan untuk mengetahui aktivitas siswa selama proses pembelajaran. Dalam hal ini penulis menggunakan lembar observasi sebagai berikut :

LEMBAR PENILAIAN AKTIVITAS BELAJAR SISWA

\begin{tabular}{|l|l|l|l|l|}
\hline No & Aspek Penilaian & Baik & Cukup & Kurang \\
\hline 1 & $\begin{array}{l}\text { Kerja Sama } \\
\text { a. Aktif memberi ide dalam membuat } \\
\text { gambar pohon yang bagus. } \\
\text { b. Aktif berunding dengan kelompoknya } \\
\text { sebelum menjawab pertanyaan. } \\
\text { c. Aktif menjawab membentuk kertas } \\
\text { warnamenjadi bentuk buah jika jawabn } \\
\text { kelompoknya benar. }\end{array}$ & & & \\
\hline 2 & $\begin{array}{l}\text { Sportivitas } \\
\text { a. Melaksanakan permainan sesuai } \\
\text { aturan (tidak berbuat curang) } \\
\text { b. Menerima kekalahan/ kemenangan } \\
\text { dalam permainan dengan lapang dada. }\end{array}$ & & & \\
\hline 3 & $\begin{array}{l}\text { Pantang Menyerah } \\
\text { a. Berusaha keras untuk bisa menjawab } \\
\text { semua pertanyaan dalam permainan. } \\
\text { c. Berusaha keras membuat kelompoknya } \\
\text { menjadi juara. }\end{array}$ & & & \\
\hline
\end{tabular}

Keterangan $: 80-100=$ Baik

$$
\begin{aligned}
& 60-79=\text { Cukup } \\
& 40-59=\text { Kurang }
\end{aligned}
$$

\begin{tabular}{|c|l|l|}
\hline NAMA & ANGGOTA KELOMPOK & NILAI KELOMPOK \\
KELOMPOK & 1. & \\
& 2. & \\
& 3. & \\
& 4. & \\
\hline
\end{tabular}


Analisis kuantitatif untuk mengetahui hasil belajar siswa setelah dilaksanakan tes formatif. Untuk menganalisis tingkat keberhasilan atau persentase keberhasilan siswa setelah proses belajar mengajar dilakukan dengan cara memberikan evaluasi berupa soal tes tertulis pada setiap akhir pembelajaran.Analisis ini dihitung dengan menggunakan statistik sederhana yaitu:

a. Untuk menilai ulangan atau tes formatif

Peneliti melakukan penjumlahan nilai yang diperoleh siswa, yang selanjutnya dibagi dengan jumlah siswa yang ada di kelas tersebut sehingga diperoleh rata-rata tes formatif dapat dirumuskan:

$$
\bar{X}=\frac{\sum X}{\sum N}
$$

Dengan $\quad: \bar{X} \quad=$ Nilai rata-rata

$\Sigma \mathrm{X}=$ Jumlah semua nilai siswa

$\Sigma \mathrm{N}=$ Jumlah siswa

b. Untuk ketuntasan belajar

Ada dua kategori ketuntasan belajar yaitu secara perorangan dan secara klasikal. Berdasarkan petunjuk pelaksanaan belajar mengajar kurikulum IPS di SMP Negeri 2 Menganti, yaitu seorang siswa telah tuntas belajar bila telah mencapai skor $75 \%$ atau nilai 75, dan kelas disebut tuntas belajar bila di kelas tersebut terdapat $85 \%$ yang telah mencapai daya serap lebih dari atau sama dengan $75 \%$. Untuk menghitung persentase ketuntasan belajar digunakan rumus sebagai berikut: $P=\frac{\sum \text { Siswa.yang.tuntas.belajar }}{\sum \text { Siswa }} \times 100 \%$

\section{HASIL DAN PEMBAHASAN}

HASIL YANG DICAPAI DENGAN PENGGUNAAN METODE PERMAINAN PASANG POHON BERBUAH Siklus I

Pada tahap Planing, peneliti bersama dengan tim MGMPS IPS SMP Negeri 2 Menganti mempersiapkan perangkat pembelajaran yang terdiri dari RPP 1, soal tes formatif 1, lembar observasi, nomor dada siswa dan alat-alat pengajaran yang mendukung.

Pada tahap Action dan Observation, pelaksanaan kegiatan belajar mengajar untuk siklus I dilaksanakan di kelas VII A dengan jumlah 32 siswa. Dalam hal ini 
peneliti bertindak sebagai guru pengajar. Sedangkan guru IPS yang lain yang tergabung dalam tim MGMPS IPS bertindak sebagai observer. Adapun proses belajar mengajar mengacu pada RPP yang telah dipersiapkan. Pengamatan (observation) dilaksanakan bersamaan dengan pelaksaaan belajar mengajar.Pada akhir proses belajar mengajar siswa diberi tes formatif I dengan tujuan untuk mengetahui tingkat keberhasilan siswa dalam proses belajar mengajar yang telah dilakukan. Adapun data hasil penelitian pada siklus I adalah sebagai berikut:

Rekapitulasi Hasil Tes Formatif Siswa Pada Siklus I

\begin{tabular}{|l|l|l|}
\hline No & Uraian & Hasil Siklus I \\
\hline 1 & Nilai rata-rata tes formatif & 69,68 \\
2 & Jumlah siswa yang tuntas belajar & 19 \\
3 & Persentase ketuntasan belajar & 59,38 \\
\hline
\end{tabular}

Hasil tersebut menunjukkan bahwa pada siklus pertama secara klasikal siswa belum tuntas belajar, karena siswa yang memperoleh nilai $\geq 75$ hanya sebesar $59,38 \%$ lebih kecil dari persentase ketuntasan yang dikehendaki yaitu sebesar $85 \%$.

Dalam tahap Reflection, kami mengadakan refleksi bersama-sama tim MGMPS IPS SMP Negeri 2 Menganti di ruang laboratorium sesaat setelah pembelajaran di kelas selesai.Dalam refleksi ini kami berkesimpulan bahwa pelaksanaan kegiatan belajar mengajar berlangsung sebagai berikut : (1)guru kurang baik dalam memotivasi siswa dan dalam menyampaikan materi pokok pelajaran. (2) guru kurang baik dalam pengelolaan waktu. (3) siswa kurang begitu antusias selama pembelajaran berlangsung.

\section{Siklus II}

Pada tahap Planing, peneliti bersama-sama dengan tim MGMPS IPS SMP Negeri 2 Menganti mempersiapkan perangkat pembelajaran yang terdiri dari RPP 2, soal tes formatif 2 , lembar observasi, nomor dada siswa, dan alat-alat pengajaran yang mendukung.

Pada tahap Action dan Observation, pelaksanaan kegiatan belajar mengajar untuk siklus II dilaksanakan di kelas VII A dengan jumlah 32 siswa. Dalam hal ini peneliti bertindak sebagai guru pengajar, sedangkan guru-guru lain yang tergabung dalam tim MGMPS IPS SMP Negeri 2 Menganti bertindak sebagai observer. Adapun proses belajar mengajar mengacu pada rencana pelajaran dengan memperhatikan revisi pada siklus I sehingga kesalahan atau kekurangan pada siklus I tidak terulang lagi pada siklus II. Pengamatan (observasi) dilaksanakan bersamaan dengan pelaksanaan belajar 
mengajar. Pada akhir proses belajar mengajar siswa diberi tes formatif II dengan tujuan untuk mengetahui tingkat keberhasilan siswa dalam proses belajar mengajar yang telah dilakukan. Instrument yang digunakan adalah tes formatif II. Adapun data hasil penelitian pada siklus II adalah sebagai berikut :

Rekapitulasi Hasil Tes Formatif Siswa Pada Siklus II

\begin{tabular}{|l|l|l|}
\hline No & Uraian & Hasil Siklus II \\
\hline 1 & Nilai rata-rata tes formatif & 72,66 \\
2 & Jumlah siswa yang tuntas belajar & 23 \\
3 & Persentase ketuntasan belajar & 71,88 \\
\hline
\end{tabular}

Dari tabel di atas diperoleh nilai rata-rata prestasi belajar siswa adalah 72,66 dan ketuntasan belajar mencapai $71,88 \%$ atau ada 23 siswa dari 32 siswa sudah tuntas belajar. Hasil ini menunjukkan bahwa pada siklus II ini ketuntasan belajar secara klasikal telah mengalami peningkatan sedikit lebih baik dari siklus I. Adanya peningkatan hasil belajar siswa ini karena guru lebih bisa memotivasi siswa yang kurang mampu dalam mata pelajaran yang mereka pelajari. Disamping itu adanya kemampuan guru yang mulai meningkat dalam prose belajar mengajar.

Dalam tahap Reflection, peneliti bersama dengan guru-guru IPS yang tergabung dalam tim MGMPS IPS SMP Negeri 2 Menganti mengadakan refleksi di ruang perpustakaan setelah jam pelajaran selesai.Dalam refleksi ini kami berkesimpulan bahwa masih terdapat kekurangan dalam kegiatan pembelajaran yaitu : (1)guru belum maksimal dalam memotivasi siswa. (2)guru belum maksimal dalam membimbing siswa merumuskan kesimpulan/menemukan konsep. (3)guru masih belum tepat dalam pengelolaan waktu.

\section{Siklus III}

Pada tahap Planing, peneliti bersama dengan tim MGMPS IPS mempersiapkan perangkat pembelajaran yang terdiri dari RPP 3, soal tes formatif 3, lembar observasi, nomor dada siswa, dan alat-alat pengajaran yang mendukung.

Pada tahap Action dan Observation, kegiatan belajar mengajar untuk siklus III dilaksanakan di kelas VII A dengan jumlah 32 siswa. Dalam hal ini peneliti bertindak sebagai guru pengajar, sedangkan guru-guru IPS yang lain bertindak sebagai observer. Pada akhir proses belajar mengajar siswa diberi tes formatif III dengan tujuan untuk mengetahui tingkat keberhasilan siswa dalam proses belajar mengajar yang telah 
dilakukan. Instrumen yang digunakan adalah tes formatif III. Adapun data hasil penelitian pada siklus III adalah sebagai berikut:

Rekapitulasi Hasil Tes Formatif Siswa Pada Siklus III

\begin{tabular}{|l|l|l|}
\hline No & Uraian & Hasil Siklus III \\
\hline 1 & Nilai rata-rata tes formatif & 76,72 \\
2 & Jumlah siswa yang tuntas belajar & 28 \\
3 & Persentase ketuntasan belajar & 87,5 \\
\hline
\end{tabular}

Berdasarkan tabel diatas diperoleh nilai rata-rata tes formatif sebesar 76,72 dan

dari 32 siswa yang telah tuntas sebanyak 28 siswa dan 4 siswa belum mencapai ketuntasan belajar. Maka secara klasikal ketuntasan belajar yang telah tercapai sebesar 87,5\% (termasuk kategori tuntas). Hasil pada siklus III ini mengalami peningkatan lebih baik dari siklus II.

Dalam tahap Reflection, peneliti bersama-sama dengan guru-guru IPS yang tergabung dalam tim MGMPS IPS SMP Negeri 2 Menganti mengadakan refleksi di ruang guru setelah jam pelajaran selesai.Dalam refleksi ini kami mengkaji apa yang telah terlaksana dengan baik maupun yang masih kurang baik dalam proses belajar mengajar . Dari data-data yang telah kami peroleh dapat duraikan sebagai berikut: (1)selama proses belajar mengajar guru telah melaksanakan semua pembelajaran dengan baik. Meskipun ada beberapa aspek yang belum sempurna, tetapi persentase pelaksanaannya untuk masing-masing aspek cukup besar. (2)berdasarkan data hasil pengamatan diketahui bahwa siswa aktif selama proses belajar berlangsung. (3)kekurangan pada siklus-siklus sebelumnya sudah mengalami perbaikan dan peningkatan sehingga menjadi lebih baik. (4)hasil belajar siswa pada siklus III mencapai ketuntasan.

Pada siklus III guru telah menerapkan Metode Permainan Pasang Berbuah dengan baik dan dilihat dari aktivitas siswa serta hasil belajar siswa pelaksanaan proses belajar mengajar sudah berjalan dengan baik. Maka tidak diperlukan revisi terlalu banyak, tetapi yang perlu diperhatikan untuk tindakah selanjutnya adalah memaksimalkan dan mempertahankan apa yang telah ada dengan tujuan agar pada pelaksanaan proses belajar mengajar selanjutnya penerapan metode tersebut dapat meningkatkan proses belajar mengajar sehingga tujuan pembelajaran dapat tercapai. 


\section{KESIMPULAN}

Setelah kami melaksanakan kegiatan pembelajaran selama 3 siklus dengan menerapkan Metode Permainan Pasang Pohon Berbuah maka kami dapat membuat kesimpulan bahwa: (1) Pembelajaran dengan menerapkan Metode Permainan Pasang Pohon Berbuah dapat meningkatkan prestasi belajar siswa yang ditandai dengan peningkatan rata-rata nilai siswa dalam setiap siklus, yaitu siklus I $(69,68)$, siklus II $(72,66)$, dan siklus III $(76,72)$. (2)Pembelajaran dengan menerapkan Metode Permainan Pasang Pohon Berbuah dapat meningkatkan pemahaman dan penguasaan siswa terhadap materi pelajaran IPS yang ditandai dengan peningkatan ketuntasan belajar siswa dalam setiap siklus, yaitu siklus I : 59,38\%), siklus II : 71,88\%, dan siklus III : 87,5\%.

Untuk melaksanakan pembelajaran dengan menggunakan Metode Permainan Pasang Pohon Berbuahmemerlukan persiapan yang cukup matang, sehingga guru harus mampu menentukan atau memilih topik yang benar-benar bisa diterapkan dengan pembelajaran menggunakan Metode Permainan Pasang Pohon Berbuahdalam proses belajar mengajar sehingga diperoleh hasil yang optimal.

\section{DAFTAR PUSTAKA}

Arikunto, Suharsimi. 2001. Prosedur Penelitian Suatu Pendekatan Praktek. Jakarta: Rineksa Cipta.

Mukhlis, Abdul. (Ed). 2000. Penelitian Tindakan Kelas. Makalah Panitia Pelatihan Penulisan Karya Ilmiah untuk Guru-guru se-Kabupaten Tuban.

Poerwodarminto. 1995. Kamus Besar Bahasa Indonesia. Jakarta: Bina Ilmu.Suryabrata, Sumadi. 1989. Psikologi Pendidikan. Yogyakarta: Andi Offset. Supriyono, Agus.2012 . Cooperative Learning . Yogjakarta : Pustaka Pelajar Wahyono, Hari . 2005. Metodologi Penelitian Tindakan Kelas. Malang : Universitas Kanjuruhan. 